\title{
MODERN GREEK ORTHODOX SERMON: LINGUISTIC FEATURES
}

\author{
Svitlana Shepitko \\ Mariupol State University, Mariupol, Ukraine \\ elti@mdu.in.ua \\ Mariia Smyrnova \\ Mariupol State University, Mariupol, Ukraine \\ elti@mdu.in.ua
}

\begin{abstract}
The paper focuses on the essential problem of religious communication analysis. It is aimed to study linguistic means representing Orthodox sermon in Modern Greek. 2000 Orthodox sermons of the $20^{\text {th }}$ century in Modern Greek were analysed. The authors outline linguistic and communicative features of the Modern Greek Orthodox sermon as well as define its genre specifics. Having analysed the language of the Orthodox communication, the authors outlined two opposite processes, namely terminologisation and determinologisation of the religious lexicon. The results of the research show that the social changes in the world in the late $20^{\text {th }}$ century, led to some changes in the lexicon and in the semantics of the religious discourse. In the Orthodox sermons, the figures of speech are used, highlighting the author's intention. The complex extended sentences with subordinate components, comparisons, explicitations, appellatives and quotations are typical of sermon in Greek. Although the sermon is delivered in Demotic Greek, in some ways it reflects the phonetic, morphological, structural, lexical and word-building features of Katharevousa. The sacred lexicon performs the liturgical function: it is used in written sacred texts and prayers in church. The vernacular language performs missionary function. The communicative space of the sermon is formed from the perspective of Orthodox theological worldview.
\end{abstract}

Keywords: religious communication; Orthodox sermon; Modern Greek; sacred lexicon.

\section{Introduction}

The Christian religious discourse as an interpersonal communication opens with the sermon of the religious teaching to the people (Salahova, 2013, p. 5). The interest in the Orthodox sermon phenomenon is confirmed by numerous papers on its lexical, semantic and communicative specifics. However, the Orthodox sermon in Modern Greek has not yet been analysed by Ukrainian linguists. Some attempts have been made by researchers from theological seminaries, but mainly when analysing translations from Ancient Greek for example, the Russian translation of the Ancient Greek text of sermon on the Feast of Encaenia at Jerusalem, which is a part of the corpus of the so-called "Greek Ephrem" by A.V. Gusev (Gusev, 2013, p.179) etc.

Thus, the aim of the paper is to analyse lexical, semantic, syntactical and communicative features of the Modern Greek Orthodox sermon as well as to define its genre specifics.

Before analysing the main linguistic characteristics of the preaching style, the term "church preaching" must be defined and its basic strategy must be determined. In Greek, the term "sermon" has several synonyms - ol o $\mu \imath \lambda i \varepsilon \varsigma$ (homilies), $\tau \alpha \kappa \eta \rho v ́ \gamma \mu \alpha \tau \alpha$ (Evangelistic sermons), $\tau \alpha \lambda \dot{o} \gamma l \alpha$ (topical sermons), each of them having its own functional features. The Dictionary of Modern Greek provides a generalised

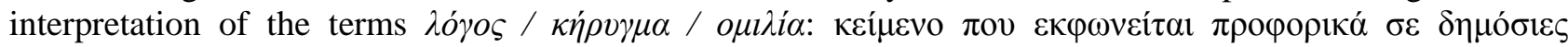

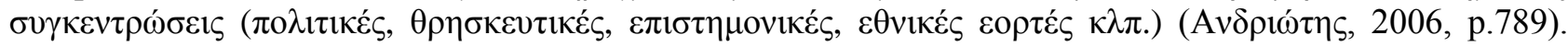
The communicative approach states that a sermon - is a fundamental original speech genre of religious communication, which is didactically orientated. A church sermon is a verbal genre of religious and didactic character, where the priest addresses the faithful during the liturgy. A Church sermon is the main genre of religious communication, which belongs to a religious discourse. The specifics of a sermon lies in its delivery in the mother tongue which is understandable to the parish. A sermon introduces the listener to the space of a polylogue as he is in a dialogue not only with himself and the world around, but with God as well. A sermon as a form of religious communication is a preacher's monologue, which he addresses the congregation. A sermon represents both a "direct religious action" and a metadiscourse of religion. It is a speech about God and to Him. The homiletics itself studies the word of God (Lischer, 2011, p. 5).

The Greek linguists, as well as theologians and historians in their investigations, outline the exact origin

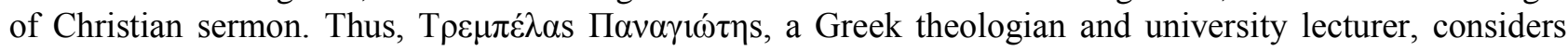
that the calling And he said unto them, Go ye into all the world, and preach the gospel to every creature (Mark 16:15) was the beginning of Christian sermon, spread all over the world by the apostles. The researcher states that "in principle, preaching is nothing else but a mean of communication and a language of

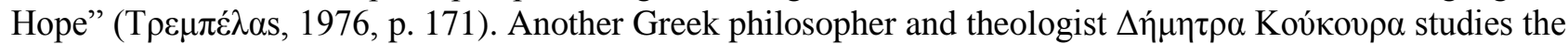
ecclesiastical rhetoric and Christian sermon in the frameworks of linguistics. The researcher states that since the first millennium, the Greek-speaking Orthodox Church has been preserving a wonderful heritage of 
functional hymns as the most incomparable art. This very poetic language invests the spiritual experience from the experience of the mystery of the faith which is incomprehensible to the human mind and becomes a prayer and thanksgiving of the worshiping community to God. At the beginning of the third millennium Modern Greek language significantly differs from the written language of operative texts, resulting in the

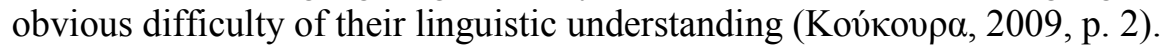

\section{Method}

The rhetorical structure of the sermon represents the theory of the so-called "inner word" or "inner

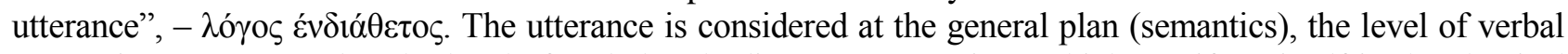
expression (syntax) and at the level of verbal embodiment (pragmatics), which manifests itself in the classical division of the general rhetorics into invention, disposition and illocution. Ch.V. Morris suggests considering the same three aspects in semiotics. The relations between the signs are considered by syntactics (syntax), the semantic content is the subject of semantics and the relations between the signs and their users are studied by pragmatics (Perez Hernandez, 2011, p. 38). In our paper, the analysis of the characteristics of Orthodox sermons in Modern Greek is based on this traditional pattern of linguistic analysis. Analysis of linguistic features of different levels of the language is important because without their detailed review and description it is impossible to have an insight into the content and the communicative fabric of the sermon as a genre of religious discourse.

In this analysis, we rely on 2000 Orthodox sermons of the $20^{\text {th }}$ century in Modern Greek by M $\eta \tau$.

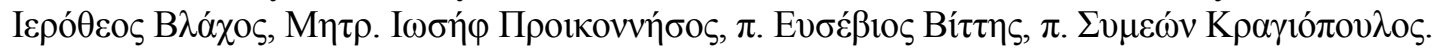

\section{Results and Discussion}

\section{Lexical and semantic features of Orthodox sermon in Modern Greek}

In describing the language of the Orthodox preaching genre as a whole, we state that it is formally and notionally conservative which is caused by the need of maintaining the dogmatic potential of the discourse. The linguistic means of mystical experience are verbalised by euphemisms, tropes, elevated and expressive lexicon, positive and negative expressive lexis, - all the means that provide not the exact rationalisation of the utterance's referent only, but its intuitive understanding as well.

Distinct boundaries of the lexicon of the Orthodox discourse can hardly be determined, but the common lexis is in its basis with terminology in its core. Terminological religious lexicon is represented by various thematic groups. Theological and religious terminology lexicons are consubstantial. Theological terms include the terms the theology as a science operates with. In addition to theological terms, the religious lexicon itself includes common lexis of non-terminological religious nature, such as historicisms, archaisms:

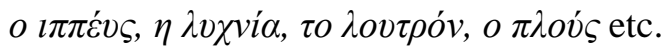

In analysing the language of Orthodox communication, two opposite processes can be viewed, namely terminologisation and determinologisation of the religious lexicon. The first process is a shift of colloquial units into terminological ones. For example, the term "cathedra" was borrowed with the meaning of "episcopal throne" from Byzantine Greek in late 1700, where $\kappa \alpha \theta \delta \delta \rho \alpha$ - with the meaning of "the throne of the bishop", "bema in the church where the sermon is read", "half-pace for the preacher", "bench, seat" is a derivative based on "kat(a)" (as) and "hedra" (seat). The modern meaning of the term (a specially equipped platform, from which lectures, reports and other performances are made to the audience; the union of teaching stuff belonging to a particular branch of science in a college or university department) is a derivative and has been recorded in dictionaries only since the early $20^{\text {th }}$ century. The other process is

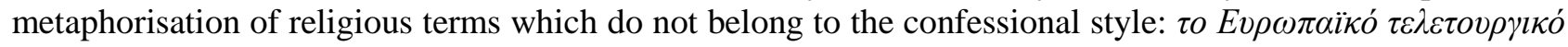

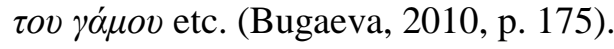

Due to the processes of secularisation and globalisation, a significant layer of the religious vocabulary is marked as obsolete, i.e. historicisms and archaisms. For example, a lexicon, which until recently was marked in dictionaries as historicisms or which was absent in dictionaries: $\eta \chi \lambda \alpha \mu v \delta \alpha \alpha\left(\chi \lambda \alpha \mu v^{\prime}\right), o \chi \imath \tau \dot{\omega} v(\alpha \varsigma), \eta$

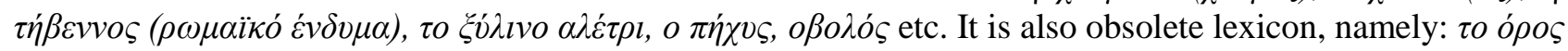

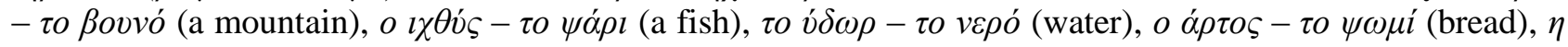

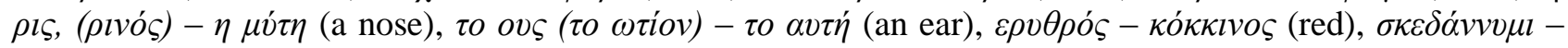
$\sigma \kappa o \rho \pi i \zeta \omega$ (to scatter), $v \omega-\beta \rho \varepsilon^{\prime} \chi \omega$ (to wet) etc.

In analysing the synonymous vocabulary in the Orthodox sermon, our attention was drawn to the fact that some of the terms just seem to be synonymous, for example, $\pi \rho \varepsilon \sigma \beta v \tau \varepsilon \dot{\varepsilon} \rho o \varsigma$ - is a term that indicates a character (as well as a post) of the Christian pastor, who in the church hierarchy is below a bishop and higher than a deacon. The term $\pi \dot{\alpha} \pi \alpha \varsigma$ has a narrower meaning than the term $\pi \rho \varepsilon \sigma \beta v \tau \varepsilon \dot{\varepsilon} \rho o \varsigma$ since it concerns only the sanctifying (i.e. liturgical) functions of the clergyman. But on the other hand its meaning is broader, 
since a deacon, presbyteral and episcopal states are three degrees of the official priesthood in Church. Also in

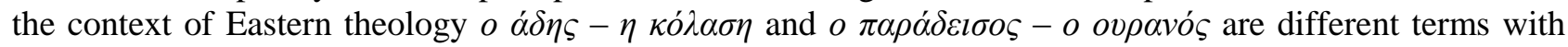
different semantics, they are not synonymous and cannot replace each other as Hell (Hades) and Paradise mean a temporary state, whereas Gehenna and Heaven mean eternal state.

In Greek sermon contextual antonyms are verbalised by different root terms $\alpha v \alpha \chi \omega ́ \rho \eta \sigma \eta-\kappa o l v o ́ \beta ı$, by

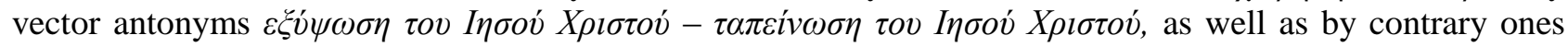
$\sigma \iota \omega \pi \eta^{\prime}-\imath \sigma \nu \chi i ́ \alpha-\mu \alpha \kappa \rho o \lambda o \gamma i \alpha$.

Interlingual homonyms can be identified as one more phenomenon. For example, Russian and Ukrainian term трапеза is used in religious context to denote a lunch or a dinner, it is any food or drink taken by a family at home or by monks in a monastery. However, the Greek term $\tau \rho \alpha ́ \pi \varepsilon \zeta \alpha$ is devoid of religious significance and is commonly used in the following meanings: 1) a table; 2) food; 3) a bank.

Paronymy arouses linguists' special interest. Thus, in Orthodox communication there are special pairs

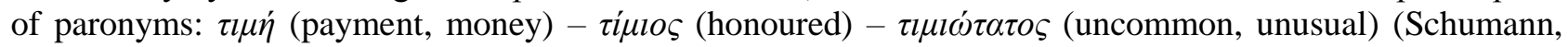
2011, p. 178). The notorious incident in history happened because of mistranslation of paronyms denoting the head of Moses. In Michelangelo's sculpture it came out adorned with horns. It was because of incorrect translation of phrases from following Ancient Greek text of the Old Testament: And it came to pass, when Moses came down from mount Sinai with the two tables of testimony in Moses' hand, when he came down from the mount, that Moses wist not that the skin of his face shone while he talked with him (Exodus 34:29). In translation of the Bible into Latin (the Vulgate) made by St. Jerome in the $4^{\text {th }}$ century, "coronatus" (lat. radiant) was mistakenly replaced by the word "cornutam" (lat., horned). Michelangelo did not know any other translations and therefore the statue of Moses by Michelangelo depicts a horned Patriarch (Schumann, 2011, p. 162).

One more process is expansion of the meaning and development of polysemy not only in the language of adherents' social groups, but also in common lexis under the influence of religion. The Greek lexical item $\rho \alpha \beta \delta o$ ó $\chi \varsigma \varsigma$ was used to name a lector - a Roman civil servant who was a bodyguard to magistrates who held the imperium. Nowadays this term is also used in the modern meaning of "myrmidon of the law".

I. Bugaeva (2010) describes the dynamic process of semantic transformation of the religious lexicon. Greek lexical item $\pi \lambda \dot{\eta} \rho \omega \mu \alpha$ is known to most of the Greeks in the modern meaning of "crew", "team". But it was used in the religious context to stand for 1) a payment; 2) completeness, entirety; 3) content - in the phrase $\tau o \pi \lambda \eta \dot{\rho} \omega \mu \alpha \tau \eta \varsigma \gamma \eta \varsigma$ - "the earth and the fullness thereof".

The lexicon of Modern Orthodox adherents is characterised by neologisms. In Greek, neologisms originate mainly through borrowings and then become exoticisms: ... $\alpha \pi \dot{\alpha} 8 \varepsilon \tau \omega \dot{v} v \kappa \alpha l \alpha \dot{\alpha} v \omega v \pi o \chi \rho \varepsilon \dot{\theta} \theta \eta \kappa \alpha v$

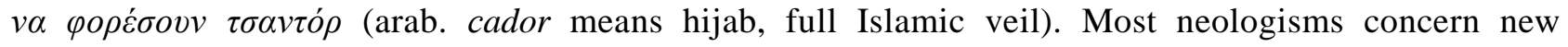

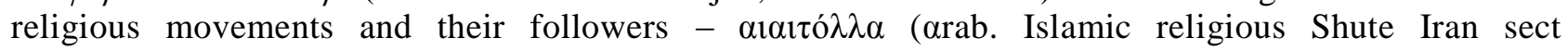
leader). Emotionally expressive and stylistic heterogeneity of the Orthodox religion lexicon reflecting mental peculiarities of religious consciousness is verbalised by high, neutral and common (vernacular) registers (Bugaeva, 2010, p.117). The religious lexis can be defined as both official and conversational

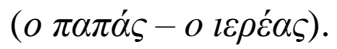

It is also necessary to point out some lexical peculiarities of sermon in Modern Greek. Liberated from the Turkish yoke in 1830, Greece recognises Katharevousa as the state language which became the official language of government agencies, science and education. But in 1974, the language problem was resolved in favour of Demotic Greek, the language of "high" literature used in translating of the New Testament. Although the sermon is delivered in Demotic Greek, but in some ways it reflects the phonetic, morphological, structural, lexical and word-formation features of Katharevousa. For example, in Katharevousa they use accusative case, whereas in Demotic Greek it exists only in some fixed phrases (such as $\delta \dot{\xi} \xi \alpha \tau \theta \theta \varepsilon \dot{\omega}$, $\delta \dot{\xi} \xi \alpha$ ool o $\theta \varepsilon \delta \delta_{\varsigma}$ ). The professional lexis of clergymen also has some specificity. In church terminology, they use the words $\alpha \rho \tau o \varsigma$, not $\psi \omega \mu i$; oivos, not $\kappa \rho \alpha \sigma i$; $\chi \theta \theta \dot{v} \varsigma$, not $\psi \dot{\alpha} \rho \imath$, etc. (Zvonskaya, 2007, p. 273).

Thus, we can state that the social changes that took place in the world of the late $20^{\text {th }}$ century led to some changes in the lexicon and in the semantics of religious terms.

\section{Syntactic features of the Orthodox sermon in Modern Greek}

Syntactic features of the Russian sermon are analysed in the papers by Bobyrova (2007), Burtsev (2012), Chelysheva (1999), Krylova (2005), Morozova (1998), Rastorgueva (2005), Savin (2009), and others. Considering their contribution, we can define the following characteristics of syntax in Orthodox sermons of Modern Greek: 
1) prevalence of complex sentences over simple ones; sometimes it also depends on the personality of a certain preacher for example if he is a representative of the Slavic diaspora, the structure of the sentences

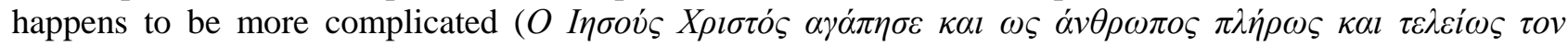

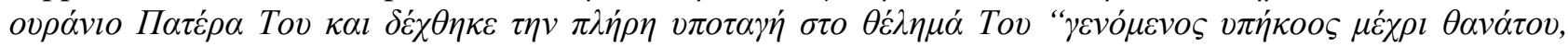

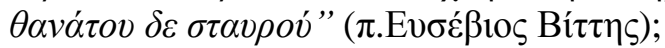

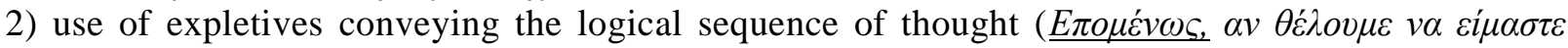

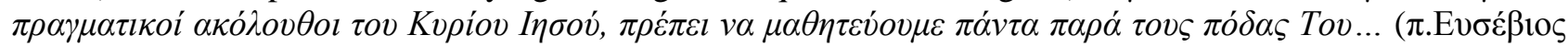

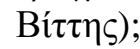

3) use of participial and adverbial phrases (as dangling adverbial modifiers and definitives) ( $\Sigma v \chi v \alpha ́$

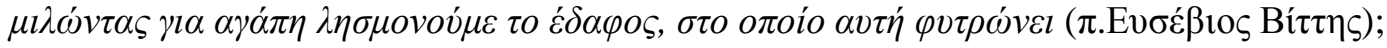

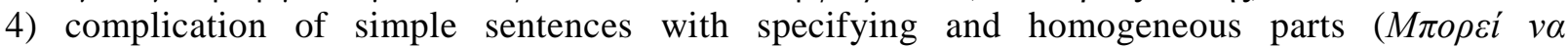

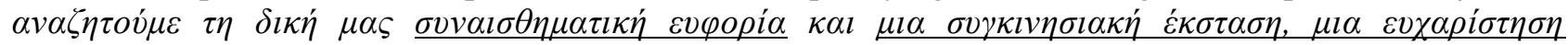

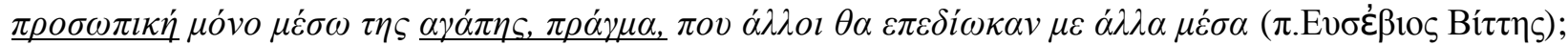

5) quotations from the Bible, the Holy Tradition, prayers, psalms for the purpose of argumentation of

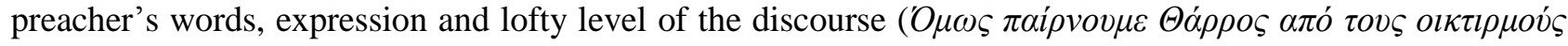

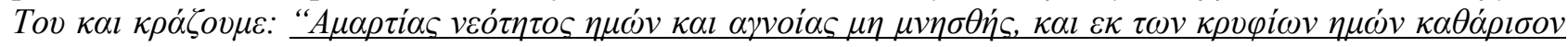

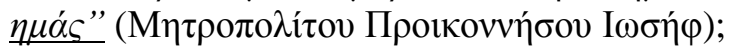

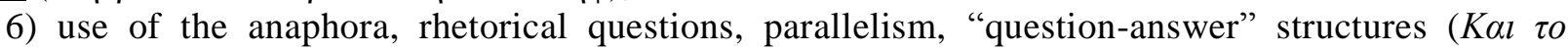

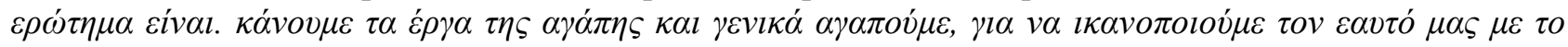

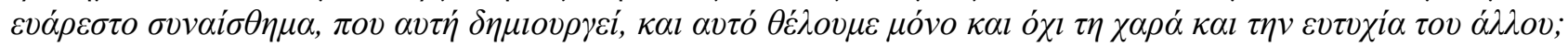

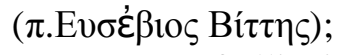

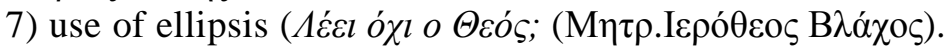

8) active use of expanded appellatives conveying a welcoming attitude of the preacher to the

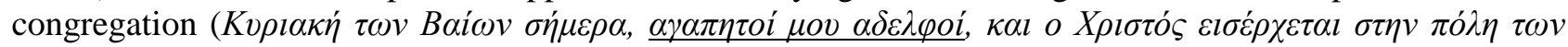

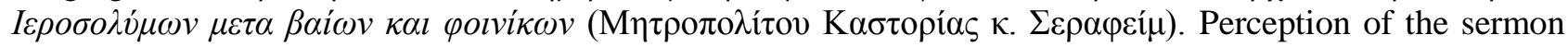
inevitably generates a response - if it not verbally expressed, it still arises in human soul. In addition, the use of reference to God, the Mother of God and the saints concluding the sermon is made by the first person in

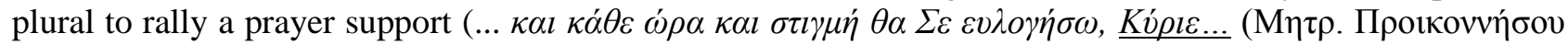
I $\omega \sigma \eta ́ \varphi) ;$

9) use of imperative clause with a predicate verb in the form of the first person in plural, expressing the

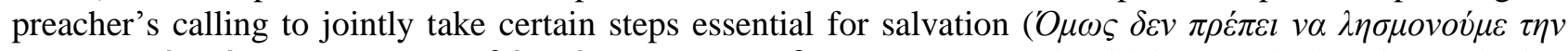

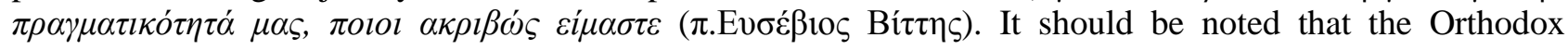
sermon is not characterised by the use of imperative clauses implying an order or absolute prohibition, the preacher puts himself on a par with the flock, showing that all people are equal, implementing the biblical revelation "If any man desires to be first, the same shall be last of all, and servant of all" (Mark 9:35).

10) use sentences with several subordinate clauses which are joined succeedingly to place greater focus

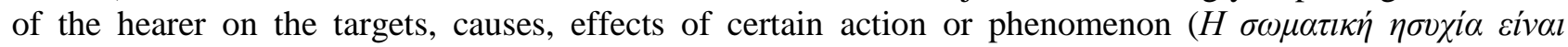

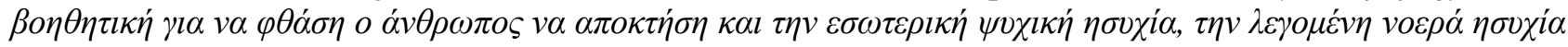

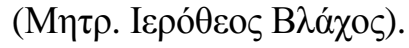

11) use of predicative constructions with the same object or subject of addressing for an the purpose of emphasising what is relevant to the addressee in terms of the preacher. In this way, the author makes a logical stress on a predictive part which contains the most important information. Sometimes predicative constructions are used in the narrative to indicate the sequence of events. Also, repetition (if predicate constructions are used in order to draw adherents' attention to a number of deeds) is needed for a further spiritual growth or, otherwise, to the actions that lead to destruction. This increases the expression and the importance of a

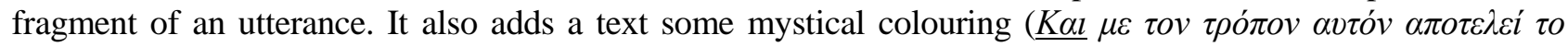

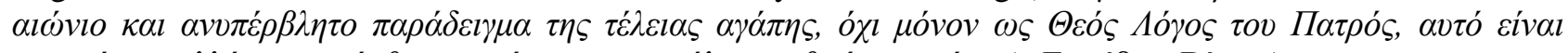

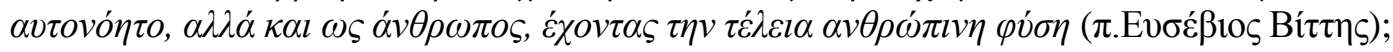

12) use of the "Definition / explanation - interpretation of the definition" syntactic structure which at the beginning helps focus on the attribute - the quality or characteristics of a person. Then at interpreting the

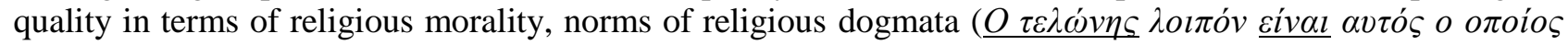

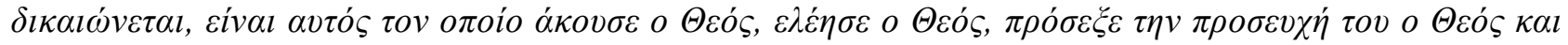

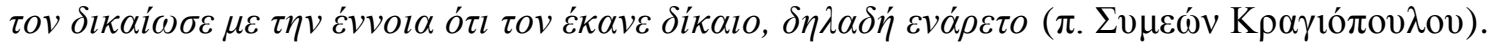

In the Orthodox sermons, the figures of speech are used, highlighting the author's intention Due to the use of figures of speech a phrase becomes semantically deeper and is constructed nonlinearly, since the relations among its elements form a complex meaningful space. The figures of speech used in the Orthodox sermon can be divided into such groups as the figures of extraction (they can emerge by adding, omitting, 
full or partial repetition, modification, distribution or permutation of words, phrases or parts of a particular construction). The figures of extraction are constructive patterns of presenting content by means of which certain aspects of thought are compared or emphasised. There are also figures of dialogue which are rhetorical figures used to create the effect of dialogue in the monologues speech, i.e. inclusion of certain elements to the recipient's speech which represent imaginary or real conversation between the priest, the audience or a third party.

\section{Communicative and discursive features of the Orthodox sermon in Modern Greek}

The communicative aim of Orthodox sermon is to strengthen the faith of all the participants of communication. It is achieved by public demonstrations of religious beliefs by the preacher, this call of the homilet to keep the commandment of the Gospel (Zvezdin, 2012, p. 65). Implementation of specific purposes of Orthodox sermon depends on the audience's level of confessionalization as well as on specific strategies of a particular preacher. If the audience is not religiously homogeneous, achievement of these goals is not a result of a preacher's comprehensive goal-setting, but is a consequence of differential perception of the flock (Schumann, 2011, p. 162).

The communicative space of the sermon is caused by Orthodox theological worldview. Oral, dialogic, illustrative and rhetoric nature of the sermon is marked as its distinctive features. The collective, cultural, personal and hyper communication we can see in a sermon. The Orthodox text categories include thematic coherence, situational conditioning, dynamics, social orientation, inhomogeneous structuring, non-discretion. Among the discursive categories of the Orthodox sermon there are categories of the author, the addresser and the recipient, informativity, intertextuality, content, integrity, coherence, genre and stylistic identity, participants and circumstances of communication.

Despite sermon is a monologue, it is still dialogic because preaching is impossible without flock. In addition, the preacher's speech includes even more authoritative sources of Orthodoxy in the form of citation, indirect speech or as an exposition. All these communication features, text and discursive categories form a peculiar and unique space of the Orthodox sermon.

Among the general genre features of Orthodox sermon in Modern Greek we can lay emphasis on the following. Homiletics teaches not to explicate one's own "I", to reduce it to the level of "WE", thus putting oneself lower the level of congregation and even considering oneself at its feet. But the personal "I" is widely used when a Greek preacher illustrates the debate inside the human mind from the first-person singular: $\Delta \varepsilon v \sigma o v \underline{\delta i v \omega}$

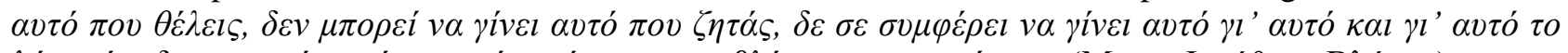

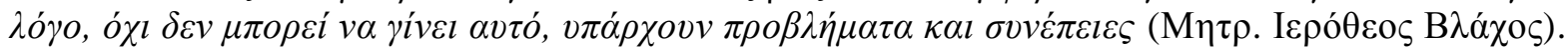

Complex extended sentences with subordinate clauses, comparisons, explicitations, appellatives,

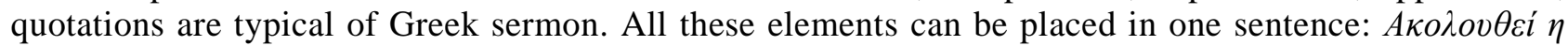

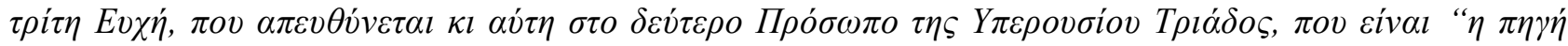

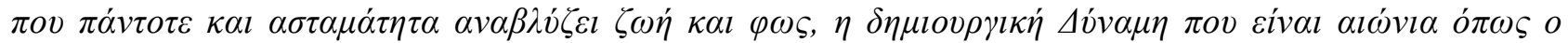

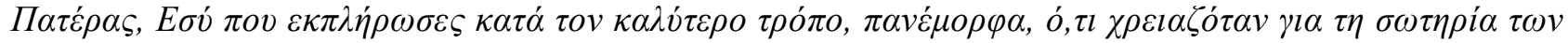

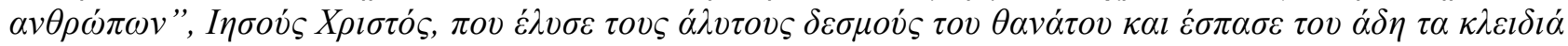

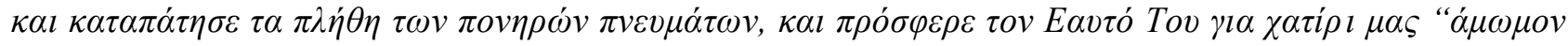

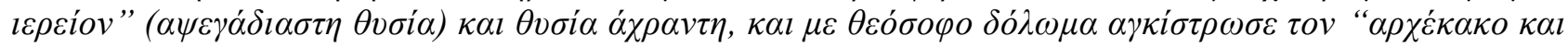

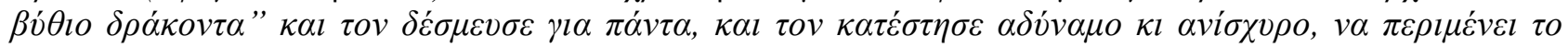

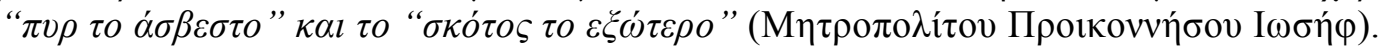

Along with the vernacular language, the sacred one functions as well. The sacred language performs the liturgical function: it is used in written sacred texts and in prayers in church. The vernacular language performs the missionary function (it is used when a sermon is delivered, when personal prayers are read). Greek preachers may use both the sacred language and archaic syntax:

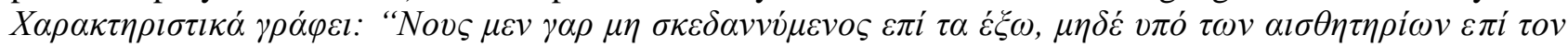

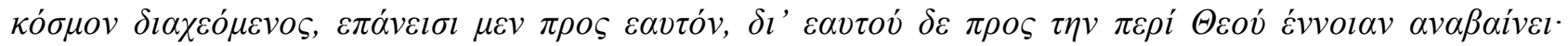

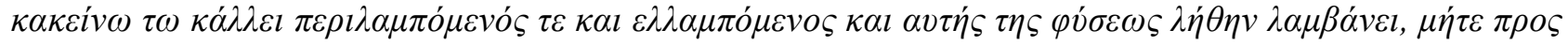

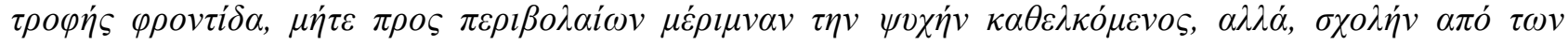

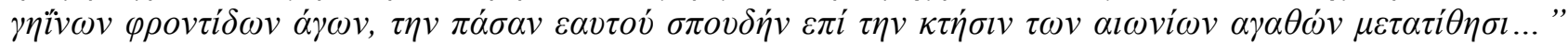

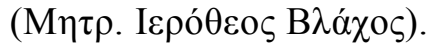

\section{Conclusions}

The analysis of the linguistic characteristics of Orthodox sermon in Modern Greek helps look at the inner process of religious communication and fully understand the need of further studies in the field of religious discourse, particularly in Greek. On the basis of theoretical conclusions, we came to the following: 
1.The lexicon of Greek Orthodox sermon is verbally and semantically conservative its core consists of terminological units. The use of archaisms in sermons performs the catechetical function. Orthodox communication demonstrates such phenomena as polysemy, homonymy, paronyms, antonymy, synonymy, neologisation verbalised in a particular communicative situation and semantically defined by it. The phenomena of lexical meaning narrowing and expansion, the process of semantic transformation of religious lexicon have also been fixed.

2. The syntax of Orthodox sermon in Modern Greek is characterised by the use of complex sentences and expletives conveying a logical sequence of thought, use of participial and adverbial phrases, quotations from the Bible, the Holy Tradition, prayers and psalms for argumentation of the preacher's words, use of anaphora, rhetorical questions, parallelism, "question / answer" structures, dialogue in direct speech, call to God, Mother of God and saints etc.

3. The communicative space of the sermon is defined by Orthodox theological worldview. Oral, dialogic, illustrative and rhetoric nature of the sermon is marked as its distinctive features.

On the whole, the theoretical and practical significance of the results obtained is determined by their contribution to communicative linguistics. The outcomes of our investigation will also stimulate the further development of a research paradigm in linguistics - theolinguistics and open up prospects for to investigation of the preaching genre on the basis of other languages, genres and religions.

\section{References:}

Bugaeva, I. (2010). Jazik pravoslavnoy sfery: sovremennoye sostoyaniye, tendenzii rasvitiya [Language of Orthodox sphere: current status and development trends]. Moscow, Russia: Moscow State University.

Gusev, V. (2013). Propoved" "Grecheskogo Yefrema" na prazdnik obnovleniya : perevod I predvariteliy kommentariy [The sermon of "the Greek Ephrem" on the feast of Encaenia: translation and preliminary observations]. Yekaterinburg, Russia: Theological seminary of Yekaterinburg.

Lischer, R. (2011). A Theology of Preaching. Durham: Labyrinth Press.

Malin, I. (2012). Sovremennaya pravoslavnaya propoved kak intertext [Modern orthodox sermon as an intertext]. Nizhny Novgorod, Russia: Linguistic University.

Perez Hernandez, L. (2011). Illokution and Cognition. Universidad de la Rioja: Servicio de Publicaciones.

Salakhova, A. (2013). Konfessionalnaya yazikovaya lichnost: kommunikativnye strategii i takniti [Confessional language personality: communicative strategies and tactics]. Tambov, Russia: Gramota.

Schumann, A. (2011). Logic in Religious Discourse. USA: Transaction Pub. https://doi.org/10.1515/9783110319576

Zvezdin, D. (2012). Pravoslavnaya propoved kak zanr zerkovno-religioznogo stilya sovremennogo russkogo literaturnogo yazika [Orthodox sermon as a genre of church and religious style in modern Russian literary language]. Chelyabinsk, Russia: Chelyabinsk State University.

Zvonska, L. (2007). Movny phenomen attykizmu i koine Novogo Zavitu [Language phenomenon of atticism and koine of the New Teatament]. Kiev, Ukraine: Taras Shevchenko National University.

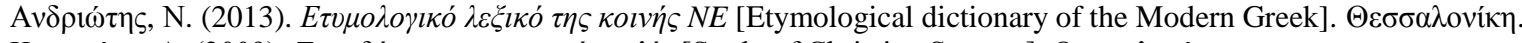

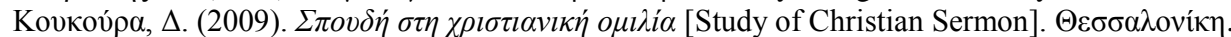

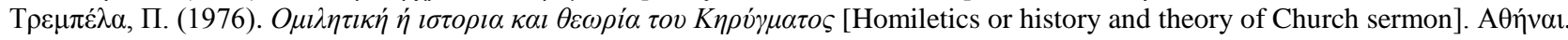

References of illustrative material:

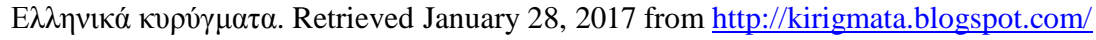

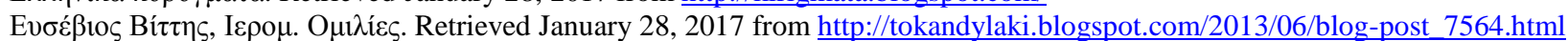

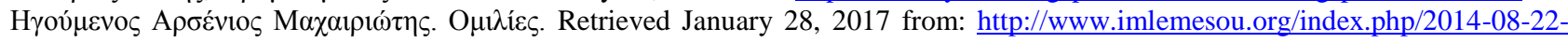
14-36-34/114-2014-09-11-05-37-23/

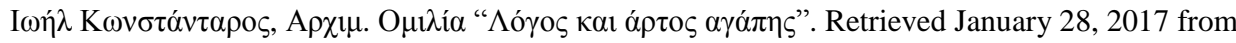
http://thriskeftika.blogspot.com/2014/08/blog-post_2.html

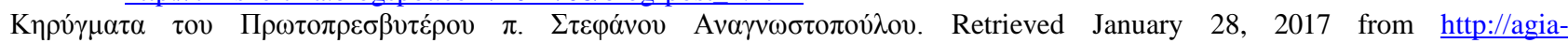
varvara.blogspot.com/2010/12/blog-post_18.html

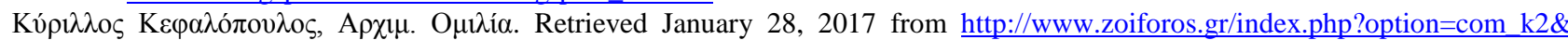
view $=$ itemlist $\&$ layout $=$ category $\&$ task $=$ category $\& i d=299 \& I t e m i d=522 /$

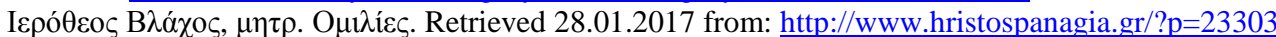

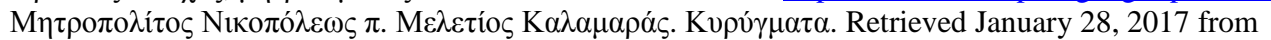
http://www.enoriako.info/index.php?option=com content \&view=article\&id=313:2013-11-30-16-22$37 \&$ catid $=101 \&$ Itemid $=520 /$

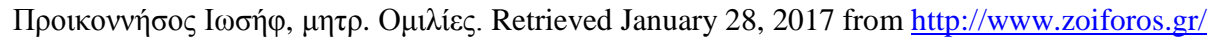

$\Sigma \varepsilon \beta \alpha \sigma \mu 1 \omega \tau$ đ́́ from http://www.imkastorias.gr/index.php/o-mitropolitis/2013-09-10-09-20-52/egkyklioi-eorties/item/1223-m-ega-thavmatis-ikoumenis/

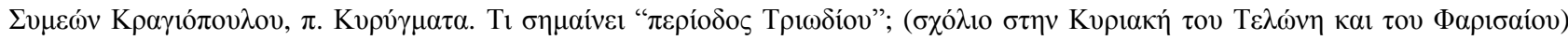
Retrieved January 28, 2017 from http://paterikakeimena.blogspot.com/2011/02/blog-post_06.html 